\title{
Physiological responses of matrinxã (Brycon amazonicus) fed different levels of vitamin $C$ and submitted to air exposure
}

\author{
Janessa Sampaio de ABREU ${ }^{1}$ and Elisabeth Criscuolo URBINATI ${ }^{1,2}$
}

\begin{abstract}
The role of vitamin C on physiological responses of matrinxã (Brycon amazonicus) submitted to air exposure was analyzed. Nine hundred fish $(70.15 \mathrm{~g})$ were distributed in fifteen $500 \mathrm{l}$ boxes $\left(60\right.$ fish.box $\left.^{-1}\right)$ and fed five rations (treatments): Control (no vitamin C); T100 (100 mg); T200 (200 mg); T400 (400 mg) and T800 (800 mg of vitamin C kg.ration $\left.{ }^{-1}\right)$. Each ration was offered to fish of three boxes during 60 days before the stress challenge that consisted of exposing fish to air for two minutes. Samplings were carried out for 5, 15,30 and 60 minutes after the air exposure. Blood was collected for glucose, cortisol, total protein, sodium, chloride, hematocrit, hemoglobin determination, and white and red cell count. Liver was removed for hepatosomatic index (HSI) calculation and glycogen determination. Vitamin C did not affect the levels of cortisol, chloride, total protein, hemoglobin, leukocytes, hepatic glycogen or HSI in air exposed fish. Blood glucose levels elevation observed 60 minutes after the challenge did not depend on the levels of vitamin C, nor did the drop in serum sodium levels verified 60 minutes after stressor. In general, hematocrit did not change by effect of vitamin $\mathrm{C}$ but it was lower at 15 and 30 minutes after the challenge. The number of erythrocytes decreased in fish after 5 minute sampling in all treatments, especially at 30 and 60 minutes. The air exposure evoked alterations in stress indicators of matrinxã, and the vitamin C did not alter the responses.
\end{abstract}

KEY WORDS

Brycon amazonicus, capture, stress, ascorbyl - polyphosphate.

\section{Respostas fisiológicas de matrinxã (Brycon amazonicus) arraçoados com diferentes niveis de vitamina Ce submetidos à exposição aérea}

\begin{abstract}
RESUMO
Este trabalho avaliou a participação da vitamina $C$ nos indicadoras de estresse no matrinxã (Brycon amazonicus), durante exposição aérea. Novecentos peixes $(70,15 \mathrm{~g})$ foram distribuidos em caixas de cimento (500 l) e alimentados com os tratamentos: Controle (sem vitamina C); T100 (100 mg); T200 (200 mg); T400 (400 mg); T800 (800 mg de vitamina C kg.ração-1). Cada ração foi fornecida a peixes de três caixas por 60 dias antes da aplicação do estressor, que consistiu em suspender os peixes mantendo-os no ar por dois minutos. Cinco, 15, 30 e 60 minutos depois, os peixes anestesiados foram amostrados. Foi coletado sangue para determinação de glicose, cortisol, proteina total, sódio, cloreto, hematócrito, hemoglobina, contagem de células brancas e vermelhas e o fígado removido para cálculo do indice hepatossomático (IHS) e determinação do glicogênio. Não houve diferença significativa nos valores de cortisol, cloreto, proteina total, hemoglobina, leucócitos, glicogênio ou IHS nos peixes expostos ao ar. Glicemia sangüínea aumentou aos 60 minutos após desafio, independente dos niveis de vitamina $C$ testados. Nivel de sódio sérico diminuiu em uma hora após estressor, independente do tratamento. Hematócrito não foi afetado pela vitamina $C$, mas foi menor aos 15 e 30 minutos após exposição aérea. O número de eritrócitos diminuiu em todos os tratamentos aos 30 e 60 minutos. A exposição aérea provocou estresse no matrinxã e a vitamina $C$ não minimizou as respostas fisiológicas.
\end{abstract}

\section{PALAVRAS- CHAVE}

Brycon amazonicus, captura, estresse, ascorbil polifosfato.

\footnotetext{
${ }^{1}$ Aquaculture Center, University of Sao Paulo State (CAUNESP). Via de Acesso Prof. Paulo Donato Castelane, 14.884-900. Jaboticabal, SP, Brazil. Phone: +55 (016) 3203-2110. Fax: +55 (016) 3203-2268

${ }^{2}$ Corresponding author: bethurb@caunesp.unesp.br
} 


\section{INTRODUCTION}

The expansion of fish farming has made farmers more concerned about losses in production. Common practices of fish farming, such as capture, confinement, transport and water quality that are stressful to fish, increase the incidence of disease and mortality and impair growth and survival (Barton \& Iwama, 1991; Wendelaar Bonga, 1997). Immunostimulants have been shown to induce protection against disease and stimulate nonspecific defense mechanisms (Anderson, 1992; Sakai, 1999). Some vitamins are known to improve the immune system responses and vitamin $\mathrm{C}$ has shown to reduce stress (Fletcher, 1997). Studies testing the dietary supplementation of vitamin $\mathrm{C}$ have evaluated its benefits on the immune system and the capacity of stress prevention in fish (Waagbo, 1994).

Channel catfish (Ictalurus punctatus) fed vitamin C deficient diets were susceptible to ammonia toxicity and low dissolved oxygen concentrations (Mazik et al., 1987), while seabream (Sparus aurata) fed ascorbic acid free diet presented significant hyperglycemia and a wider variation of the plasma cortisol level when submitted to a 24-hour hypoxia (Henrique et al., 1998).

Stressors in aquaculture are unavoidable and cause many harmful effects. Strategies to attenuate them should be considered, including the use of rations supplemented with appropriate levels of vitamin $\mathrm{C}$ before fish handling. Few studies on the vitamin $\mathrm{C}$ requirement of neotropical fish are available and the effect of this vitamin on the stress response is still not clear.

Matrinxã (Brycon amazonicus), an Amazonian species, is an omnivorous fast growing fish (Saint Paul, 1986) whose economic importance as farmed fish has increased lately. Studies on the responses of this species to transport (Carneiro \& Urbinati, 2001; Carneiro \& Urbinati, 2002; Urbinati et al., 2004), confinement (Rocha et al., 2003) and to alarm substance (Ide et al., 2003) are available, however, no data are known either on the physiological responses evoked by air exposure of fish during capture or on the effects of vitamin $\mathrm{C}$ as a stress reduction factor.

This work evaluated the role of vitamin $\mathrm{C}$ on the responses (hormonal, metabolic, ionic and hematological) of matrinxã submitted to air exposure.

\section{MATERIAL AND METHODS}

The experiment was carried out at the Aquaculture Center of the São Paulo State University (CAUNESP), Jaboticabal, SP, Brazil. Nine hundred fish (weight $70.15 \pm 18.04 \mathrm{~g}$; standard length $18.04 \pm 1.47 \mathrm{~cm}$; mean \pm S.E.M.) were randomly distributed in fifteen 5001 boxes $\left(60\right.$ fish.box $\left.{ }^{-1}\right)$. A peletized vitamin C free ration $(28 \%$ crude protein and $4,000 \mathrm{Kcal}$ crude energy. $\mathrm{kg}^{-1}$ ) was ground and vitamin $\mathrm{C}$ added to make five diets: Control (no vitamin C); T100 (100 mg); T200 (200 $\mathrm{mg}$ ); T400 (400 mg) and T800 (800 mg vitamin C kg.ration $\left.{ }^{1}\right)$. The rations were then repeletized, stocked in dark plastic bags and maintained at $4{ }^{\circ} \mathrm{C}$. The vitamin $\mathrm{C}$ in the control diet was measured following a titulometric method adapted from Ranganna (1977), AOAC (1975) and Instituto Adolfo Lutz (1985) and just traces were found.

The levels of vitamin tested were established according to previous studies with native fish (Martins, 1995; Fracalossi, 1998; Chagas and Val, 2003). Ascorbyl polyphosphate (Stay C 35, Roche) was the source of vitamin C.

Each of the five rations was offered twice daily to fish of three boxes for 60 days before the stress challenge that consisted of exposing fish to air for two minutes. Twenty-eight fish of each treatment were transferred to $100 \mathrm{~L}$ plastic boxes (four boxes treatment ${ }^{-1}$, seven fish.box ${ }^{-1}$ ), where they remained for 48 hours until the challenge. The procedure was repeated three times (three days) to avoid samplings longer than one hour, and each time was considered a block (replicate). For the challenge, fish were taken out of the water for two minutes by polyethylene nets previously adapted to the boxes. Samplings were carried out $5,15,30$ and 60 minutes after they returned to the water. All the fish in each box were anesthetized (benzocaine, 66mg.t${ }^{1}$ ), and four were sampled. The sampled boxes were excluded from the experiment to avoid additional stress. Two fish were bled by puncturing of the caudal vessels with heparinized syringes, and blood was used for glucose (King \& Garner, 1947) and hemoglobin (Labtest Kit) analysis. A sample collected in glass capillary tubes was centrifuged for hematocrit determination and in another sample, the erythrocyte and leukocyte number was counted in a Neubauer chamber. Heparinized blood was centrifuged and plasma was used for total protein (Gornall et al., 1949) and chloride (Labtest Kit) determinations. Another two fish were bled with syringes without anti-coagulating. Serum was separated for cortisol (Radioimmuno-assay with a CoatCount Kit, Diagnostic Products Corporation LA) and sodium (ions selected-ISELAB DRAKE) analysis. The fish were weighed and the liver removed and weighed for hepatosomatic index (HSI) calculation [(liver weight (g) b/body weight (g) x 100] and glycogen determination (Moon et al., 1989).

Water temperature (maximum $24.1 \pm 0.10^{\circ} \mathrm{C}$ and minimum $\left.22.0 \pm 0.12{ }^{\circ} \mathrm{C}\right)$ and dissolved oxygen $\left(4.99 \pm 0.06 \mathrm{mg} \cdot \mathrm{l}^{-1}\right)$ were measured daily, and $\mathrm{pH}(5.92 \pm 0.03)$, electric conductivity $\left(41.48 \pm 0.76 \mu \mathrm{S} . \mathrm{cm}^{-1}\right)$ and total ammonia $(0.112 \pm 0.002$ mg. $\left.\mathrm{l}^{-1}\right)$ measured weekly. These parameters were within an acceptable range for matrinxã rearing.

\section{STATISTICAL ANALYSIS}

A randomized complete block design ( $\mathrm{RCB}$ ) was employed in factorial scheme (five treatments $x$ four sampling times). Data were analyzed by two-way variance analysis (ANOVA), by SAS software and presented as means \pm S.E.M. The means were compared by Tukey test (5\%). 


\section{RESULTS}

The dietary vitamin $\mathrm{C}$ did not affect the values of cortisol, chloride, total protein, hemoglobin, leukocytes, liver glycogen and hepatosomatic index (HSI) in air exposed fish (Table 1). The elevation in blood glucose levels observed 60 minutes after the stressing challenge did not depend on the levels of vitamin $\mathrm{C}$ tested (Fig. 1). The serum sodium level decreased at 60 minutes after exposing to stressor (Fig. 2). In general, hematocrit did not change by effect of vitamin $\mathrm{C}$ but it was lower at 15 and 30 minutes after the challenge (Fig. 3). The number of erythrocytes decreased after the five-minute sample in fish of all treatments, especially at 30 and 60 minutes (Fig. 4).

\section{DISCUSSION}

Increase of plasma cortisol is a primary response in fish submitted to different kinds of stressors (Barton \& Iwama, 1991;

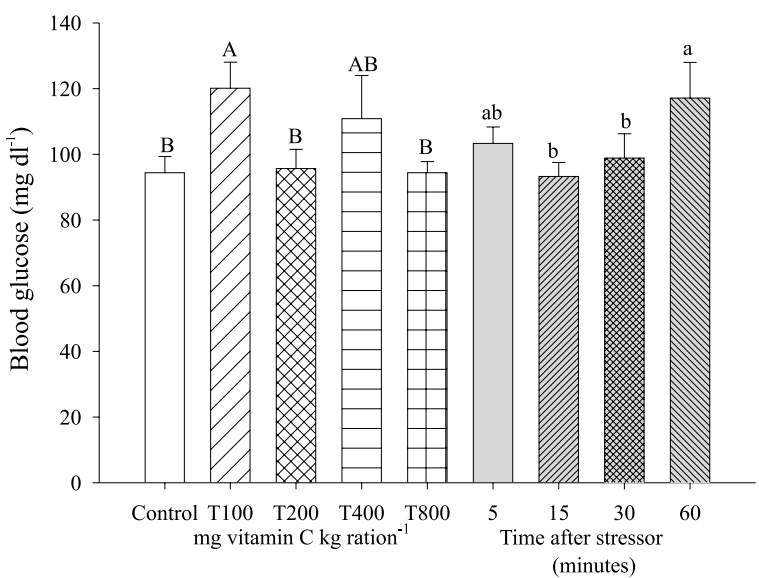

Figure 1 - Blood glucose $\left(\mathrm{mg} \mathrm{dl}^{-1}\right)$ of matrinxã fed different levels of vitamin $\mathrm{C}$ and submitted to air exposure. Different capital letters indicate difference among treatments and small letters among sampling times.

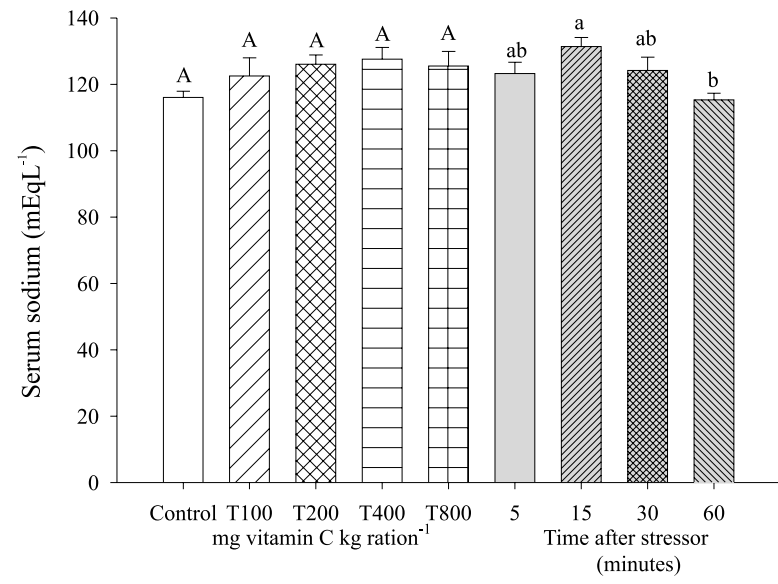

Figure 2 - Serum sodium ( $\mathrm{mEq} \mathrm{L}^{-1}$ ) of matrinxã fed different levels of vitamin $\mathrm{C}$ and submitted to air exposure. Different capital letters indicate difference among treatments and small letters among sampling times.

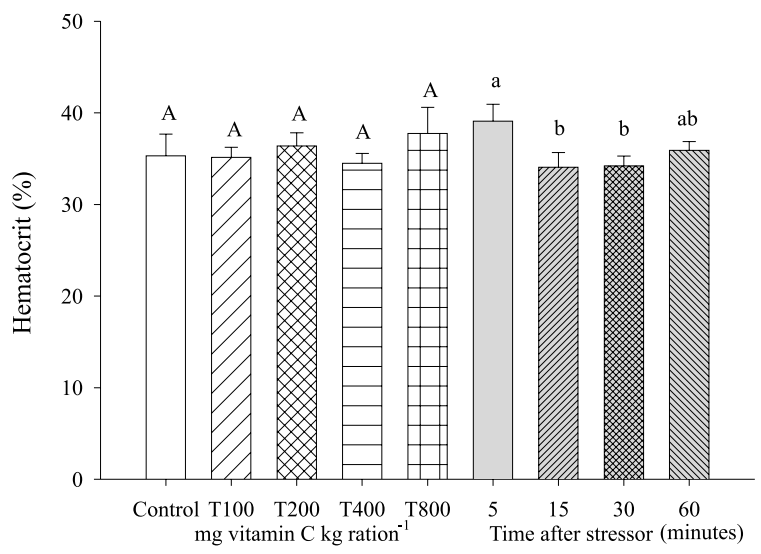

Figure 3 - Hematocrit (\%) of matrinxã fed different levels of vitamin C and submitted to air exposure. Different capital letters indicate difference among treatments and small letters among sampling times.

Table 1 - Serum cortisol, plasma chloride, plasma total protein, hemoglobin, leukocytes, liver glycogen and hepatosomatic index (HSI) of matrinxã fed different levels of vitamin $\mathrm{C}$ during 60 days and submitted to air exposure.

\begin{tabular}{|c|c|c|c|c|c|c|c|c|}
\hline & & 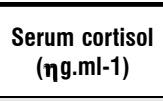 & $\begin{array}{l}\text { Plasma chloride } \\
\text { (mEq.I-1) }\end{array}$ & $\begin{array}{c}\text { Plasma total } \\
\text { protein } \\
\text { (mg ml-1) }\end{array}$ & $\begin{array}{l}\text { Hemoglobin } \\
(\mathrm{g} \mathrm{dl}-1)\end{array}$ & $\begin{array}{c}\text { Leukocytes } \\
\text { (cell } \mu \mathrm{l}-1 \text { ) x } 103\end{array}$ & $\begin{array}{l}\text { Liver glycogen } \\
\text { (g } 100 \mathrm{~g} \text { tissue-1) }\end{array}$ & $\begin{array}{l}\text { HSI } \\
(\%)\end{array}$ \\
\hline \multirow{5}{*}{$\underset{\text { ration-1 }}{\mathrm{mg} \text { vitamin } \mathrm{Ckg}}$} & 0 & $116.2 \pm 9.0$ & $75.3 \pm 2.7$ & $5.9 \pm 0.4$ & $11.3 \pm 0.5$ & $5.3 \pm 0.5$ & $8.8 \pm 0.6$ & $1.4 \pm 0.03$ \\
\hline & 100 & $93.6 \pm 17.9$ & $82.1 \pm 3.3$ & $5.3 \pm 0.5$ & $11.6 \pm 0.3$ & $5.8 \pm 0.5$ & $7.0 \pm 0.3$ & $1.4 \pm 0.04$ \\
\hline & 200 & $113.5 \pm 6.6$ & $84.4 \pm 3.5$ & $6.8 \pm 0.4$ & $11.3 \pm 0.5$ & $4.9 \pm 0.4$ & $8.3 \pm 0.4$ & $1.4 \pm 0.05$ \\
\hline & 400 & $108.0 \pm 3.3$ & $87.2 \pm 3.3$ & $5.9 \pm 0.5$ & $11.3 \pm 0.3$ & $5.2 \pm 0.3$ & $8.6 \pm 0.4$ & $1.4 \pm 0.02$ \\
\hline & 800 & $120.8 \pm 9.1$ & $88.3 \pm 1.6$ & $6.7 \pm 1.2$ & $12.7 \pm 0.5$ & $5.0 \pm 0.5$ & $9.0 \pm 0.3$ & $1.4 \pm 0.05$ \\
\hline \multirow{4}{*}{$\begin{array}{l}\text { Minutes after } \\
\text { stressor }\end{array}$} & 5 & $111.7 \pm 11.2$ & $83.2 \pm 4.2$ & $5.8 \pm 0.5$ & $12.0 \pm 0.4$ & $5.7 \pm 0.5$ & $8.6 \pm 0.3$ & $1.3 \pm 0.02$ \\
\hline & 15 & $120.6 \pm 7.0$ & $86.6 \pm 2.1$ & $6.9 \pm 0.3$ & $10.9 \pm 0.4$ & $5.1 \pm 0.2$ & $8.2 \pm 0.6$ & $1.4 \pm 0.02$ \\
\hline & 30 & $107.8 \pm 8.3$ & $84.1 \pm 2.7$ & $6.1 \pm 0.4$ & $11.8 \pm 0.2$ & $5.0 \pm 0.5$ & $7.9 \pm 0.6$ & $1.4 \pm 0.03$ \\
\hline & 60 & $101.6 \pm 10.9$ & $79.9 \pm 3.5$ & $5.8 \pm 0.8$ & $11.7 \pm 0.6$ & $5.2 \pm 0.2$ & $8.6 \pm 0.4$ & $1.3 \pm 0.04$ \\
\hline
\end{tabular}

Mean \pm S.E.M. No significant differences were found among treatments and sampling times 


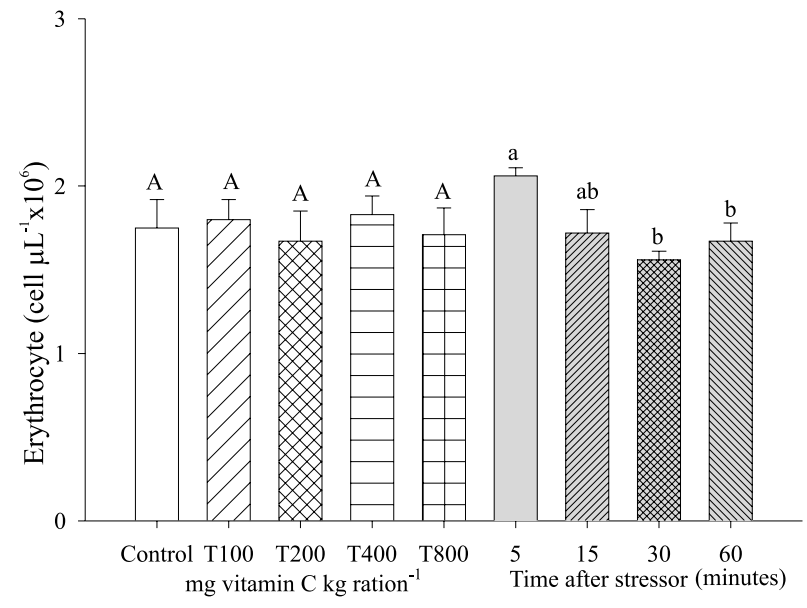

Figure 4 - Erythrocyte number (cell $\mathrm{mL}^{-1} \times 10^{6}$ ) of matrinxã fed different levels of vitamin $C$ and submitted to air exposure. Different capital letters indicate difference among treatments and small letters among sampling times.

Wendelaar Bonga, 1997). The cortisol values before stress were not measured, but the level at five minutes after air exposure (110 ng.ml $\left.{ }^{-1}\right)$ was similar to that observed in juvenile matrinxã after transport stress (97 ng. $\mathrm{ml}^{-1}$ ) (Urbinati et al., 2004) and higher than the pre-stress value described by those authors $(60$ ng.ml $\left.{ }^{-1}\right)$. In adults the pre-stress levels were around $110 \mathrm{ng} . \mathrm{ml}^{-}$ ${ }^{1}$, which doubled after a four hour transport (Carneiro \& Urbinati, 2001).

It has been hypothesized that high levels of vitamin $\mathrm{C}$ might inhibit cortisol biosynthesis by preventing the conversion of unsatured fatty acids into cholesterol ester which is the precursor of the hormone molecule (Montero et al., 1999). However, studies suggest that post-stress cortisol concentration is not dependent on vitamin C (Johnson \& Ainsworth, 1991, Li et al., 1998; Ortuño et al., 2003) as observed in our study. According to Dabrowska et al. (1991) the relationship between plasma cortisol and tissue concentration of ascorbate is not known in fish, and questions relating to ascorbic acid status and steroidogenesis are still unclear. Their results in common carp (Cyprinus carpio) showed that a normal versus high ascorbate intake did not influence the physiological stress indicators, such plasma cortisol, not supporting the hypothesis that high concentration of ascorbate would inhibit steroidogenesis. The vitamin $\mathrm{C}$ requirements of matrinxã is not yet established, but the doses tested were within the range determined for other native species: $139 \mathrm{mg} \mathrm{kg} \cdot$ ration $^{-1}$ for pacú (Piaractus mesopotamicus) (Martins, 1995), $25 \mathrm{mg} \mathrm{kg.ration}{ }^{-1}$ for acará (Astronotus ocellatus) (Fracalossi et al., 1998) and $100 \mathrm{mg}$ $\mathrm{kg} \cdot$ ration $^{-1}$ for tambaqui (Colossoma macropomum) (Chagas \& Val, 2003).

Blood glucose is the secondary response most used to quantify stress in fish. The hyperglycemia reported in several teleosts during stress is primarily mediated by catecholamines and lately by cortisol (Wendelaar Bonga, 1997). Increase in blood glucose and cortisol is reported in several studies (Benfey \& Biron, 2000; Sadler et al., 2000; Carneiro \& Urbinati, 2001; Urbinati et al., 2004) and, similarly to the cortisol response, excepting for T100 fish, vitamin C did not interfere in the blood glucose response of fish in this study. However, the glucose values found after air exposure were more elevated than the pre-stress values described

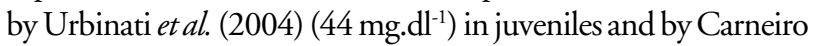

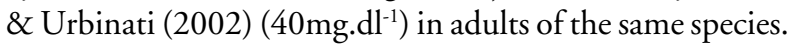

Liver glycogen did not change either by influence of the vitamin $\mathrm{C}$ or by the air exposure and the values were similar to those found by Urbinati \& Carneiro (2001) in adult fish before a stressor. Similarly, the concentration of total plasma protein did not differ. Elevated cortisol during stress may play a role in the immediate production of glucose by glycogenolysis, contributing to depletion of liver and muscular reserves of glycogen and protein (Mommsen et al., 1999). The stressor applied to matrinxã might not have been intense enough to elicit such responses.

Hematological parameters are considered good stress indicators in fish, since catecholamines and cortisol induce changes in blood cells. Their stimulatory effect, promote increase of oxygen consumption by tissues and fast differentiation and proliferation of erythrocytes (Morgan \& Iwama, 1996). The increase of catecholamines concentration may result in erythrocytes release to the blood stream by spleen contraction (McDonald \& Milligan, 1997). Increase of parameters involving red blood cells, such as hemoglobin and hematocrit, has been observed in response to stress (Benfey \& Biron, 2000; Wojtaszek et al., 2002; Urbinati et al., 2004). However, vitamin C did not affect hematocrit of matrinxã after air exposure in this study, differing with the findings by Barros et al. (2002) in tilapia (Oreochromis niloticus), whose elevation of hematocrit was directly related to the dietary vitamin $\mathrm{Clevels.} \mathrm{The} \mathrm{erythrocyte} \mathrm{number}$ decreased at 15 minutes of air exposure, and the values were not affected by vitamin C. Similarly, vitamin C did not change the hemoglobin. These results are similar to verified by Tort et al. (1996) and Sadler et al. (2000) in seabream (Sparus aurata) and Atlantic salmon (Salmo salar) submitted to crowding stress since no changes either in hematocrit or in hemoglobin were observed in these species.

Changes in number of white blood cells were observed in fish under stress (Ellis, 1981). Decrease in lymphocyte and increase in neutrophil number are frequently reported in stressed fish (Tort et al., 1996; Rotlant et al., 1997; Benfey \& Biron, 2000; Iida \& Kurogi, 2001). No significant differences were observed in the total number of leukocyte of matrinxã along the samplings and the values obtained (4,9 to 5,8 cell $\mu \mathrm{L}^{-1} \times 10^{3}$ ) were higher than those described by Tavares-Dias et al. (1999) for the species $\left(2,6\right.$ cell $\left.\mu \mathrm{L}^{-1} \times 10^{3}\right)$. The red and white blood cell count may reflect the stress degree of fish, but a number of 
factors make the diagnostic hematology a great challenge among fish, due to the variety of fish species and their diversity in morphological form and ecological functions (Hrubec \& Smith, 2000).

Some works have reported the vitamin $\mathrm{C}$ role on specific and non-specific immune responses in fish (Waagbo, 1994; Verlhac et al., 1998). However, according to the indicators used, the vitamin $\mathrm{C}$ did not affect the immune system response of matrinxã submitted to air exposure. Li et al. (1998) verified, in channel catfish (Ictalurus punctatus) that high levels of dietary vitamin C did not evoke increase of disease resistance or significant effect on antibody production after Edwardsiella ictaluri challenge. Our results suggest that the acute stress response of matrinxã was not altered by vitamin $\mathrm{C}$ addition.

After stress, plasma sodium and chloride concentration may decrease, since catecholamine elevation induce the increase of gill permeability, resulting in alteration of blood electrolytes levels (Eddy, 1981). Comparing the chloride levels observed in this work ( 75.25 to $\left.88.27 \mathrm{mEq} \cdot \mathrm{L}^{-1}\right)$ to the pre-stress values described by Urbinati et al. (2004) (120.05 mEq.L $\left.\mathrm{L}^{-1}\right)$ in juveniles of the species, it is possible to suggest a hipochloremia state on fish, disagreeing with that verified by Tomasso et al. (1980) in hybrid striped bass (Morone chrysops females with Morone saxatilis males) submitted to confinement stress. Likewise with chloride, a decrease of sodium levels was observed after stress. The serum sodium levels found (115.31 to $\left.131.38 \mathrm{mEq} . \mathrm{L}^{-1}\right)$ were lower than the basal obtained by Carneiro \& Urbinati (2001) in adults (165mEq. $\left.\mathrm{L}^{-1}\right)$. Carmichael et al. (1983) also verified, in smallmouth bass (Micropterus dolomieui), decrease of sodium levels after capture and transport. The electrolytes levels obtained after air exposure showed that vitamin $\mathrm{C}$ did not affect their profile.

The results of this work, supported by results of other studies with the same species, suggest that air exposure for 2 minutes evokes hematological, hormonal, metabolic and electrolytic alterations in matrinxã. Also, vitamin C does not alter the stress responses of matrinxã fed with different dietary levels or sampled after air exposure.

\section{ACKNOWLEDGEMENTS}

The authors would like to thank CNPq for the scholarship for the first author, Mrs Damares Perecim Roviero for technical assistance, Dr Euclides Braga Malheiros for help in the statistical analyses and the Aquaculture Center of the University of São Paulo State (CAUNESP) for fish donation and facilities.

\section{LITERATURE CITED}

Anderson, D.P. 1992. Immunostimulants, adjuvants, and vaccine carriers in fish: application to aquaculture. Annu. Rev. Fish Dis., 2: $281-307$.
A.O.A.C. 1975. Official methods of analysis of the association of official agricultural chemists. $3^{\circ}$ ed., Washington A.O.A.C. 975 pp.

Barros, M.M.; Pezzato, L.E.; Kleemann, G.K.; Hisano, H.; Rosa, G.J.M. 2002. Níveis de vitamina C e ferro para tilápia do Nilo (Oreochromis niloticus). Rev. Bras. Zootec., 31(6): 2149-2156.

Barton, B.A.; Iwama, G.K. 1991. Physiological changes in fish from stress in aquaculture with emphasis on the response and effects of corticosteroids. Ann. Rev. Fish Dis., 1: 3-26.

Benfey, T.J.; Biron, M. 2000. Acute stress response in triploid rainbow trout (Oncorhynchus mykiss) and brook trout (Salvelinus fontinalis). Aquaculture, 184: 167-176.

Carmichael, G.J.; Wedemeyer, G.A.; McCraen, J.D.; Millard, J.L. 1983. Physiological effects oh handling and hauling stress on smallmouth bass. Prog. Fish Cult., 45: 110-113.

Carneiro, P.C.F.; Urbinati, E.C. 2001. Salt as a stress response mitigator of matrinxã Brycon cephalus (Teleostei: Characidae) during transport. Aquac. Res., 32: 297-304.

Carneiro, P.C.F.; Urbinati, E.C. 2002. Transport stress in matrinxã Brycon cephalus (Teleostei: Characidae), at different densities. Aquac. Intern., 10: 221-229.

Chagas, E.C.; Val, A.L. 2003. Efeito da vitamina C no ganho de peso e em parâmetros hematológicos de tambaqui. Pesq. Agropec. Bras., 38, 397 - 402.

Dabrowska, H.; Dabrowski, K.; Meyer-Burgdorff, K.; Hanke, W.; Gunther, K. D. 1991. The effect of large doses of vitamin C and magnesium on stress responses in common carp Cyprinus carpio. Comp. Biochem. Physiol., 99A: 681-685.

Eddy, F.B. 1981. Effects of stress on osmotic and ionic regulation in fish. In: Pickering A. D. (Ed). Stress and fish. Academic Press, London. p. 77-102.

Ellis, A.E. 1981. Stress and the modulation of defense mechanisms in fish. In: Pickering A. D. (Ed). Stress and fish. Academic Press, London. p. 147-169.

Fletcher, T.C. 1997. Dietary effects on stress and health in aquaculture. In: Iwama, G.K.; Pickering, A.D.; Summer, J.P.; Schreck, C.B. (Eds). Fish Stress and Health in Aquaculture. Cambridge University Press, Cambridge. p. 223-246.

Fracalossi, D.M.; Allen, M.E.; Nichols, D.K., Oftedal, O. T. 1998. Oscars, Astronotus ocellatus, have a dietary requirement for vitamin C. J. Nutr., 128: 1745-1751.

Gornall, A.G.; Bardawill, C.J.; David, M.M. 1949. Determination of serum proteins by means of the biuret reaction. J. Biol. Chem., 4: 751-766.

Henrique, M.M.F.; Gomes, E.F.; Gouillou-Coustans, M.F.; OlivaTeles, A.; Davies, S.J. 1998. Influence of supplementation of practical diets with vitamin $\mathrm{C}$ on growth and response to hypoxic stress of seabream, Sparus aurata. Aquaculture, 161: 415-426.

Hrubec, T.C.; Smith, S.A. 2000. Hematology of fish. In: Feldman, B. V., Zinkl, J. G., Jain, N. C. (Eds). Schalm's veterinary hematology. Lippincott Williams and Wilkins, Philadelphia. p. $1120-1125$ 
Ida, T.; Kurogi, J. 2001. Stress impairs non-specific defense activity of fish. Bull. Natl. Res. Inst. Aquacult., Suppl., 5: 61-64.

Ide, L.M.; Urbinati, E.C.; Hoffmann, A. 2003. The role of olfaction in the behavioral and physiological responses to conspecific skin extract in a teleost fish, Brycon cephalus. J. Fish Biol., 63: $332-$ 343.

Instituto Adolfo Lutz. 1985. Normas Analíticas: método químico e físico para análise de alimentos. 4.ed. Editora Anvisa. São Paulo, SP. p. 345-420.

Johnson, M.R.; Ainsworth, A.J. 1991. An elevated dietary level of ascorbic acid fails to influence the response of anterior kidney neutrophils to Edwardsiella ictaluri in channel catfish. J. Aquat. Anim. Health, 3: 266-273.

King, E.J.; Garner, R.J. 1947. Colorimetric determination of glucose. J. Clin. Path., 1: 30-33.

Li, M.H., Wise, D. J., Robinson, E. H. 1998. Effect of dietary vitamin $\mathrm{C}$ on weight gain, tissue ascorbate concentration, stress response, and disease resistance of channel catfish Ictalurus punctatus. J. World Aquac. Soc., 29(1): 1-8.

Martins, M.L. 1995. Effect of ascorbic acid deficiency on the growth, gill filament lesions and behavior of pacu fry (Piaractus mesopotamicus Holmberg, 1887). Braz. J. Med. Biol. Res., 28: 563-568.

Mazik, P.M.; Brandt, T.M.; Tomasso, J.R. 1987. Effects of dietary vitamin $\mathrm{C}$ on growth, caudal fin development and tolerance of aquaculture-related stressors in channel catfish. Prog. Fish Cult., 49: 13-16.

McDonald, G.; Milligan, L. 1997. Ionic, osmotic and acid-base regulation in stress. In: Iwama, G.W.; Pickering, A.D.; Sumpter, J.P.; Schreck, C.B. (Eds). Fish Stress and Health in Aquaculture. Cambridge University Press, Cambridge, p. 119-144.

Mommsen, T.P.; Vijayan, M.M.; Moon, T.W. 1999. Cortisol in teleosts: dynamics, mechanisms of action, and metabolic regulation. Fish Biol. Fish., 9: 211-268.

Montero, D.; Marrero, M.; Izquierdo, M.S.; Robaina, L.; Vergara, J.M.; Tort, L. 1999. Effect of vitamin E and C dietary supplementation on some immune parameters of gilthead seabream (Sparus aurata) juveniles subjected to crowding stress. Aquaculture, 171: 269-278.

Moon, T.W.; Foster, G.D.; Plisetskaya E.M. 1989 Changes in peptide hormones and liver enzymes in the rainbow trout deprived of food 6 weeks. Can. J. Zool., 67: 2189-2193.

Morgan, J.D.; Iwama, G.K. 1996. Cortisol-induced changes in oxygen consumption and ionic regulation in coastal cutthroat trout (Oncorhynchus clarki clarki) parr. Fish Physiol. Biochem., 15 (5): 385-394.

Ortuño, J.; Esteban, M.A.; Meseguer, J. 2003. The effect of dietary intake of vitamins $\mathrm{C}$ and $\mathrm{E}$ on the stress response of gilthead seabream (Sparus aurata L.). Fish Shellfish Immunol. 14: 145156.

Ranganna, S. 1977. Manual of analysis of fruit and vegetable products. N. Delhi: McGraw-Hill, 634pp.
Rocha, R.M.; Carvalho, E.G.; Urbinati, E.C. 2003. Physiological responses associated with capture and crowding stress in matrinxã Brycon cephalus (Gunther, 1869). Aquac. Res., in press.

Rotllant, J.; Pavlidis, M.; Kentouri, M.; Abad, M.E.; Tort, L. 1997. Non-specific immune responses in the red porgy Pagrus pagrus after crowding stress. Aquaculture, 156: 279-290.

Sadler, J.; Wells, R.M.G.; Pankhurst, P.M.; Pankhurst, N.W. 2000. Blood oxygen transport, rheology and hematological responses to confinement stress in diploid and triploid Atlantic salmon, Salmo salar. Aquaculture, 184: 349-361.

Saint Paul, U. 1986. Potential for aquaculture of South America: a review. Aquaculture, 54: 205-240.

Sakai, M. 1999. Current research status of fish immunostimulants. Aquaculture, 172: 63-92.

Tavares-Dias, M.; Frascá-Scorvo, C.M.D.; Campos-Filho, E.; Moraes, F.R. 1999. Características hematológicas de teleósteos brasileiros. IV. Parâmetros eritroleucométricos, trombométricos e glicemia do matrinxã Brycon cephalus Günther, 1869 (Osteichthyes: characidae). ARS Vet., 15 (3): 149-153.

Tomasso, J.R.; Davis, K.B.; Parker, N.C. 1980. Plasma corticosteroid and electrolyte dynamics oh hybrid striped bass (white bass $\mathrm{x}$ striped bass) during netting and hauling. Proc. World Maricul. Soc., 11: 303-310.

Tort, L.; Sunyer, J.O.; Gómez, E.; Molinero, A. 1996. Crowding stress induces changes in serum haemolytic and aglutinating activity in the gilthead seabream Sparus aurata. Vet. Immunol. Immunopathol., 51: 179-188.

Urbinati, E.C.; Abreu, J.S.; Camargo, A.C.S.; Landines, M.A.P. 2004. Loading and transport stress of juvenile matrinxã (Brycon cephalus, Characidae) at various densities. Aquaculture, 229: 389-400.

Urbinati, E.C.; Carneiro, P.C.F. 2001. Metabolic and hormonal responses of the matrinxã Brycon cephalus (Teleostei: Characidae) to the stress of transport under the influence of benzocaine. $J$. Aquac. Trop., 16 (1): 75-85.

Verlhac, V.; Obach, A.; Gabaudan, J.; Schüep, W.; Hole, R. 1998. Immunomodulation by dietary vitamin $\mathrm{C}$ and glucan in rainbow trout (Oncorhynchus mykiss). Fish Shellfish Immunol., 8: 409424.

Waagbo, R. 1994. The impact of nutritional factors on the immune system in Atlantic salmon, Salmo salar L.: a review. Aquat. Fish Man., 25: 175-197.

Wendelaar Bonga, S.E. 1997. The stress response in fish. Physiol. Rev., 77 (3): 591-625.

Wojtaszek, J.; Dziewulska-Szwajkowska, D.; Lozinska-Gabska, M.; Adamowicz, A.; Dzugaj, A. 2002. Hematological effects of high dose of cortisol on the carp (Cyprinus carpio L.): cortisol effect on the carp blood. Gen. Comp. Endocrinol., 125: 176-183.

Recebido em 17/08/2004

Aceito em 10/10/2006 